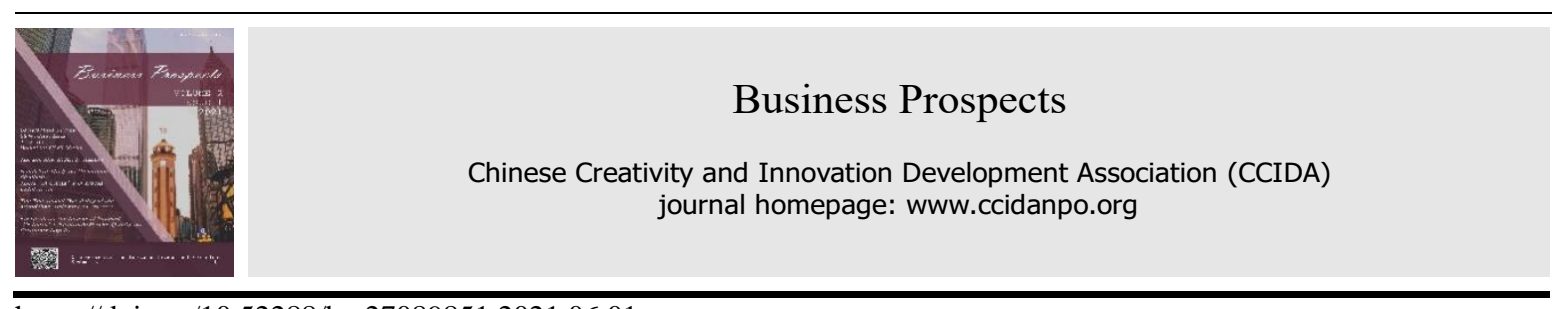

https://doi.org/10.52288/bp.27089851.2021.06.01

\title{
Regional Investigation for Economies of Development Status on Changes in Export Structure of Deterioration Terms of Trade
}

\author{
Grant G. L. Yang 1 , * \\ ${ }^{1}$ Associate Professor of School of International Business, Xiamen University Tan Kah Kee College \\ * Correspondence: grant@xujc.com
}

Received: 2021.02.13; Accepted: 2021.04.15; Published: 2021.06.01

\begin{abstract}
The theory of Deterioration Terms of Trade states that the terms of trade between primary commodities and manufactures has a negative deterministic trend. However, the terms of trade for primary commodities have improved significantly because of higher prices of raw materials and natural resources due to the rapid development of some emerging developing countries. Literatures argued that the deterioration in terms of trade is the type of country in which the goods are exported rather than the types of goods exported by such countries are primary or manufactured goods. This paper employs regression models of alternative economies to analyze the correlation between terms of trade and manufactured goods export ratio. Results demonstrated that the Prebisch-Singer Hypothesis holds for all the economies except the developed ones, and the ITTs are worsened by increases in the proportion of manufactured goods for all the economies.
\end{abstract}

Keywords: Deterioration of Terms of Trade; Prebisch-Singer Hypothesis; Development Status

\section{Introduction}

The theory of Deterioration Terms of Trade (DTT) reveals that the Net Barter Terms of Trade (NBTT) between primary commodities and manufactures has a negative deterministic trend, or so-called PrebischSinger Hypothesis (Prebisch, 1950; Singer, 1950). This is due to the abundant labor force in developing economies with lower wages and the fact that agricultural markets are like competitive markets in which productivity gains do not lead to higher profits. Developed economies, which mainly produce manufactured goods, facing an imperfectly competitive international market, which reflected their technological progress and increased labor productivity in higher monopoly prices for their products. Increased labor productivity in developing economies has often led to a decline in prices and thus worsening the terms of trade. According to DTT, many developing economies have begun to implement "import substitution" trade development strategies in order to avoid the continuing deterioration of the terms of trade caused by the export of primary commodities.

With the acceleration of the industrialization process in developing economies, they are undergoing major changes in the structure of their export commodities where the proportion of exports of manufactured goods rises rapidly and replace primary exports as the main driving force for exports. At the same time, DTT is altering from the types of exports to the types of economies. Sarkar (1986) examined the terms of trade behavior of the developing economies along with primary products and found uneven distribution of gains from trade and economic progress. The interaction between developed and developing regions through the multilateral development aided flow. Sarkar and Singer (1991) further developed the DTT of manufactured exports in 29 developing economies and regions between 1965 1985 and showed that the price index for manufactured goods exported had fallen by an average of $0.65 \%$. Ardeni and Wright (1992), however, found that the rate of decline was only about half what was predicted using the data available to Prebisch and Singer and the finding of secular deterioration was robust. The resource curse hypothesis seems anomalous as development economies since it has no clear policy implication but stands as a sad prediction (Roy et al., 2013). 
The exporting proportion of the primary goods and manufacturing goods may both present negative correlation with the terms of trade. Cashin and Pattillo (2006) examined whether there was a relationship between the commodity terms of trade and the NBTT of 42 Sub-Saharan African countries. For most countries, there was little evidence of a stable, long-run relationship between the two terms of trade series. Accordingly, the practice in the literature of proxying for movements in any given country's terms of trade by using an aggregate index of relative commodity prices was inappropriate, and was likely to engender misleading policy conclusions. Witkowska (2016) selected EU member countries to demonstrate that the Prebisch-Singer Hypothesis can be used for the explanation of the diverging terms of trade development of industrialized countries with different export structures. A possible cause lies in the differing specialization in specific export sectors of these countries and the corresponding price developments of the exported goods.

Arezki et al. (2013) re-examined the Prebisch-Singer Hypothesis using the secular trend and the short run volatility as the dynamics of relative primary commodity prices. A total of 25 series were employed and a majority of them confirmed the hypothesis that relative commodity prices followed a downward secular trend. Geronimi and Taranco (2018) revisited the Prebisch-Singer Hypothesis of a secular decline in the terms of trade of primary commodities by adopting two approaches of time series to allow the identification of a succession of three different dynamic regimes over the 1900 2016 period. They highlighted such an upward shift in primary commodities' prices was unique and could be an opportunity for developing countries specialized in primary exportations.

With the acceleration of industrialization, the structure of commodities exported has changed dramatically. Using data of manufactured goods ${ }^{1}$ from UNCTAD as an example (Figure 1), the proportion of manufactured goods exported from alternative development status declined for developed economies from $77.82 \%$ in 2000 to $71.13 \%$ in 2019 , whereas that for developing economies declined from $67.05 \%$ in 2000 to $59.14 \%$ in 2011 followed by steadily rising to nearly $70 \%$ in 2019 . During the same period, the proportion of manufactured goods exported to the world presented a consistent time-series trend to the developing economies. However, the proportion of manufactured goods exported for the transition economies remained lower and a steady decline. It deserved examining the existence of Prebisch-Singer Hypothesis and the consistency to economies of alternative development status for the two decades.

Using the time series data from 2000 to 2019, this study empirically tested the impact of the structure of export commodities on terms of trade for development-differentiated status. The proportion of manufactured

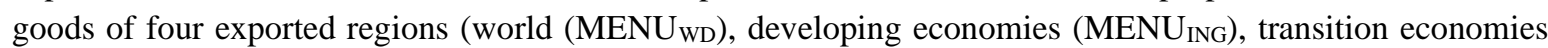
$\left(\mathrm{MENU}_{\mathrm{ION}}\right)^{2}$, and developed economies $\left.\left(\mathrm{MENU}_{\mathrm{ED}}\right)\right)$ are selected to test the theory of Deterioration Terms of Trade (DTT) on Net Barter Terms of Trade (NBTT) or the so-called Hypothesis of Prebisch-Singer.

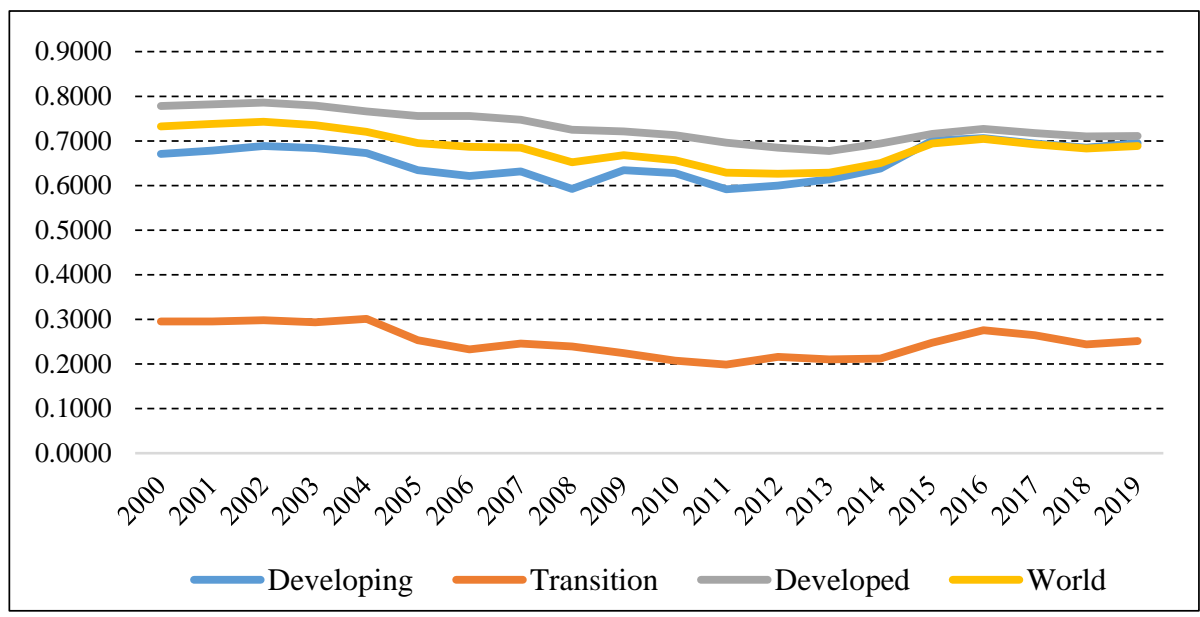

Figure 1. Time trend of the proportion of manufactured goods exported for economies of alternative development status.

\footnotetext{
1 Manufactured goods include: Leather, leather manufactures and dressed furskins; Rubber manufactures, n.e.s.; Cork and wood manufactures (excluding furniture); Paper and paper manufactures; Textile yarn and related products; Non-metallic mineral manufactures, n.e.s.; Iron and steel; Non-ferrous metals; Manufactures of metal, n.e.s.

2 Transition economies include Albania, Armenia, Azerbaijan, Belarus, Bosnia and Herzegovina, Georgia, Kazakhstan, Kyrgyzstan, Republic of Moldova, Montenegro, North Macedonia, Russian Federation, Serbia, Serbia and Montenegro, Tajikistan, Turkmenistan, Ukraine, and Uzbekistan.
} 


\section{Time Trend of China's Terms of Trade}

A classical and general linear function to analyze the changing tendency of terms of trade using a time trend variable and a lagged dependent variable (Cashin and Pattillo, 2006):

$$
\ln Y_{t}=\alpha+\beta T+\sum_{\mathrm{i}=1}^{\mathrm{m}} \beta_{i} \ln Y_{t-i}+\mu
$$

where $\beta_{i}$ is the lagged coefficients and the absolute value of $\beta_{i}$ determines the stability of terms of trade. $\left|\beta_{i}\right|<$ 1 shows that the time series data of the terms of trade are stable, and the results of the equation have good explanatory power; $\left|\beta_{i}\right|=1$ reveals that there is a unit root problem with the time series data and variable differentials are to be made for stability; $\left|\beta_{i}\right|>1$ indicates the variable cannot be regressed using the linear equation. This study applied the equation of to measure the time trend of the proportion of manufactured goods (MANU) exported for economies of alternative development status and NBTT from 2000 to 2019 (Figure 2).

Figure 2 shows that the trend variables of NBTT have generally improved over the past 20 years for the world and developing economies, while the transition and developed economies suffered with index base of 2015 as 100. Specifically, the NBTTs are highly negatively correlated with MANUs for the world (-0.7429) and the transition economies (-0.8874), highly positively correlated with MANU for the developed economies (0.8410), and lower positively correlated with MANU for the developing economies (-0.3519) (Table 1).

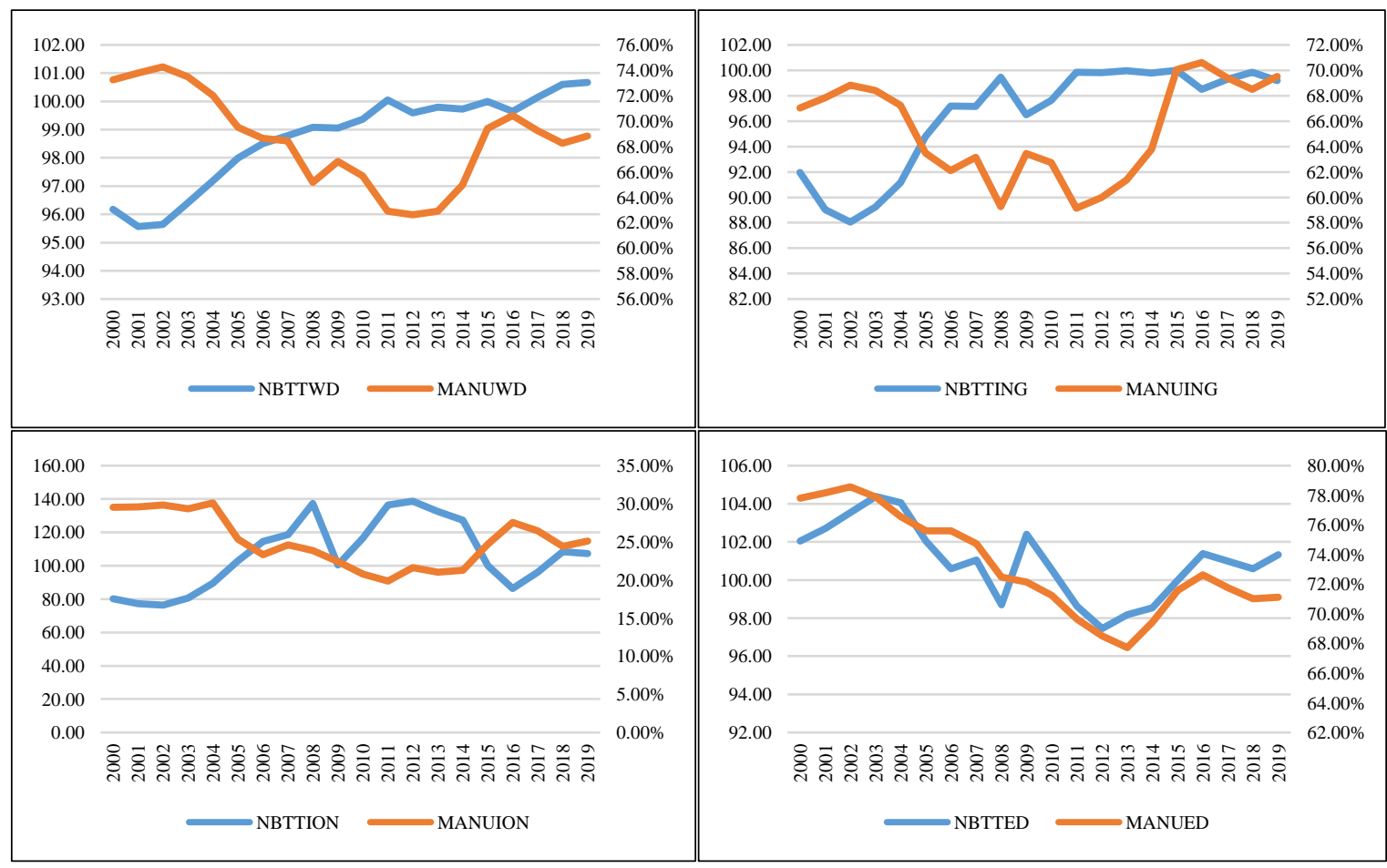

Figure 2. Time trend of the proportion of manufactured goods (MANU) exported for economies of alternative development status and NBTT.

Table 1. The correlation coefficient analysis of MANU and NBTT for economies of alternative development status.

\begin{tabular}{|c|c|c|c|c|c|c|c|c|}
\hline & NBTT $_{W D}$ & NBTT $_{\text {ING }}$ & NBTT $_{\text {ION }}$ & NBTT $_{\text {ED }}$ & MANUWD & MANUING & MANUION & MANUED \\
\hline NBTTWD $_{W}$ & 1 & & & & & & & \\
\hline NBTT $_{\text {ING }}$ & 0.9615 & 1 & & & & & & \\
\hline NBTT $_{\text {ION }}$ & 0.6644 & 0.7682 & 1 & & & & & \\
\hline NBTT $_{\text {ED }}$ & -0.6920 & -0.8344 & -0.8880 & 1 & & & & \\
\hline MANUwd & -0.7429 & -0.8188 & -0.9497 & 0.8872 & 1 & & & \\
\hline MANUING & -0.1959 & -0.3519 & -0.8172 & 0.6199 & 0.7583 & 1 & & \\
\hline MANUION & -0.7343 & -0.7970 & -0.8874 & 0.8197 & 0.9458 & 0.7158 & 1 & \\
\hline MANUED & -0.8950 & -0.9031 & -0.7822 & 0.8410 & 0.8979 & 0.3974 & 0.8406 & 1 \\
\hline
\end{tabular}


Proportion of manufactured goods exported for economies of development status are listed in Figure 3 for the economies of development-differentiated status in changes of proportion of manufactured goods exported. The developed economies present a relatively higher proportion of manufactured goods while the transition economies are the lowest. The tendency is in general decreasing from 2000 to 2011 and rising thereafter until a peak is reached in 2016 .

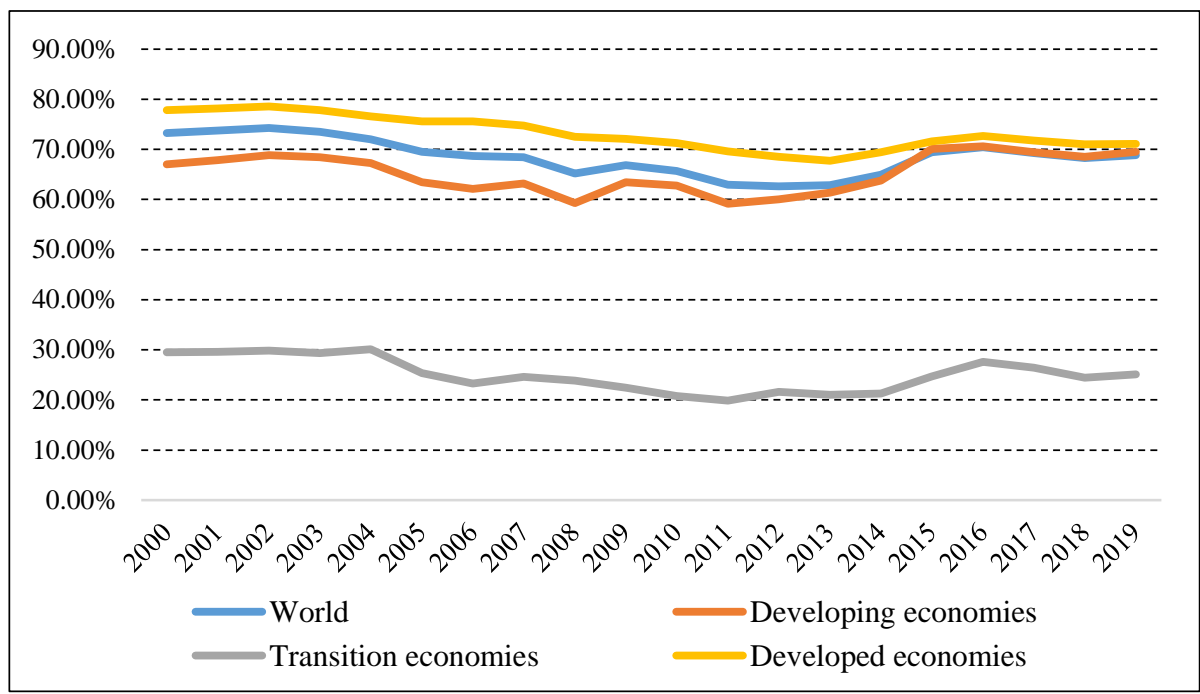

Figure 3. Proportion of manufactured goods exported for economies of development status.

\section{Development Status Investigation of Terms of Trade and Export Trade Structure}

Cointegration analysis is used in this study to investigate whether there is a long-term stable relationship between NBTT and MANU for different economies of development status. The stability of each variable is tested first for non-smooth inspection process by the unit root inspection process using the ADF method. Cointegration exists if all variables are ionized in the same order and some linear combination of these variables is stable. Finally, Granger's causality test is used to analyze whether there is a causal relationship between the variables followed by the multiple regression models. Table 2 presents unit root test results NBTT and MANU. NBTTs for all economies are non-stable at the 5\% significant level but stable for the first-order difference (they are all first-order single-order sequence I(1)).

Table 2. Trace statistics of Johansen's co-integration tests (terms of trade variables vs groups).

\begin{tabular}{ccccc}
\hline Variables & $\begin{array}{c}\text { Test type } \\
(\mathbf{C}, \mathbf{T}, \mathbf{K})^{*}\end{array}$ & ADF-statistic & $\begin{array}{c}\text { Test critical value } \\
(\mathbf{5 \%} \text { level) }\end{array}$ & Conclusion \\
\hline NBTT $_{\mathrm{WD}}$ & $(\mathrm{C}, 0, \mathbf{1 )}$ & -2.3930 & -3.0404 & Not stable \\
NBTT $_{\mathrm{ING}}$ & $(\mathrm{C}, 0,1)$ & -2.0236 & -3.0404 & Not stable \\
NBTT $_{\mathrm{ION}}$ & $(\mathrm{C}, 0,1)$ & -2.0628 & -3.0404 & Not stable \\
NBTT $_{\mathrm{ED}}$ & $(\mathrm{C}, 0,1)$ & -1.6230 & -1.0404 & Not stable \\
\hline NBTT $_{\mathrm{WD}}$ & $(0,0,0)$ & -2.8847 & -1.9614 & Stable \\
$\Delta$ NBTT $_{\mathrm{ING}}$ & $(0,0,0)$ & -3.7164 & -1.9614 & Stable \\
$\Delta$ NBTT $_{\mathrm{ION}}$ & $(0,0,0)$ & -4.1234 & -1.9614 & Stable \\
$\Delta$ NBTT $_{\mathrm{ED}}$ & $(0,0,0)$ & -4.7307 & -3.0404 & Stable \\
\hline \hline MANU $_{\mathrm{WD}}$ & $(\mathrm{C}, 0,1)$ & -1.9541 & -3.0404 & Stable \\
MANU $_{\mathrm{ING}}$ & $(\mathrm{C}, 0,1)$ & -1.4460 & -3.0404 & Stable \\
MANU $_{\mathrm{ION}}$ & $(\mathrm{C}, 0,1)$ & -1.9127 & -3.0404 & Not stable \\
MANU $_{\mathrm{ED}}$ & $(\mathrm{C}, 0,1)$ & -1.9072 & -2.9981 & Stable \\
\hline MANU $_{\mathrm{WD}}$ & $(0,0,0)$ & -5.2022 & -2.9981 & Stable \\
$\Delta$ MANU $_{\mathrm{ING}}$ & $(0,0,0)$ & -5.2022 & -2.9981 & Stable \\
$\Delta$ MANU $_{\mathrm{ION}}$ & $(0,0,0)$ & -5.2022 & -2.9981 & Stable \\
$\Delta$ MANU $_{\mathrm{ED}}$ & $(0,0,0)$ & -5.2022 & & Stable \\
\hline
\end{tabular}

${ }^{*} \mathrm{C}$ denotes intercept; $\mathrm{T}$ denotes trend; $\mathrm{K}$ denotes lag length 
Unit root test results for all proportion exported variables (MANU ${ }_{\mathrm{WD}}, \mathrm{MANU}_{\mathrm{ING}}, \mathrm{MANU}_{\mathrm{ION}}, \mathrm{MANU}_{\mathrm{ED}}$ ) are stable at the 5\% significant level except MANUION which is stable at first-order difference level. Cointegration exists only when two variables follow the same time series process, or the time series process of dependent is no more than the independent variables. Unit root test results from Table 2 demonstrate that the variables meet the prerequisites for the existence of a cointegration relationship. Johansen's co-integration tests of trace statistic can be applied in this study and the results are illustrated in Table 3.

Results of Johansen's trace statistics in Table 3 demonstrate that there is at least one co-integrated relationship between NBTT ${ }_{W D}$ and MANUWD only. For other economies, however, no co-integration can be found. The co-integration tests have demonstrated a long-term equilibrium relationship between NBTT and MANU, and the Granger's causality tests are necessary to further verify the relationship between the causes and effects. Table 4 validates that the causality exists for MANU $\mathrm{ED}_{\mathrm{E}}$ to $\mathrm{NBTT}_{\mathrm{ED}}$ in one-period lagged only. The results suggest that $\mathrm{MANU}_{\mathrm{ED}}$ affects $\mathrm{NBTT}_{\mathrm{ED}}$, while the impacts of proportion of manufactured goods exported to rest of the economies are uncertain.

Table 3. Johansen's co-integration tests.

\begin{tabular}{|c|c|c|c|c|c|c|}
\hline & MANUWD & MANUING & MANUION & MANUED & $\begin{array}{c}5 \% \text { Critical } \\
\text { Value } \\
\end{array}$ & Prob. ${ }^{* *}$ \\
\hline \multirow{2}{*}{ NBTTWD $_{W}$} & $15.6219^{*}$ & & & & 12.3209 & 0.0135 \\
\hline & $13.4744^{*}$ & & & & 11.2248 & 0.0198 \\
\hline \multirow{2}{*}{ NBTT $_{\text {ING }}$} & & 8.1393 & & & 12.3209 & 0.2261 \\
\hline & & 4.5846 & & & 11.2248 & 0.5377 \\
\hline \multirow{2}{*}{ NBTT $_{\text {ION }}$} & & & 4.4926 & & 12.3209 & 0.6397 \\
\hline & & & 4.4617 & & 11.2248 & 0.5563 \\
\hline \multirow{2}{*}{ NBTTED $_{\text {ED }}$} & & & & 5.4105 & 12.3209 & 0.5113 \\
\hline & & & & 5.3769 & 11.2248 & 0.4260 \\
\hline
\end{tabular}

${ }^{*}$ denotes rejection of the hypothesis of no co-integration at the $5 \%$ level; ${ }^{* *}$ denotes $5 \%$ Critical Value of 15.4947

Table 4. Results of Granger's causality tests.

\begin{tabular}{|c|c|c|c|c|}
\hline Null Hypothesis & $\begin{array}{l}\text { Lags to } \\
\text { include }\end{array}$ & F-Statistic & Prob. & Result \\
\hline MANU $_{W D}$ does not Granger Cause NBTT ${ }_{W D}$ & \multirow{4}{*}{1} & 0.6138 & 0.4448 & Not Reject \\
\hline $\mathrm{MANU}_{\mathrm{ING}}$ does not Granger Cause $\mathrm{NBTT}_{\mathrm{ING}}$ & & 0.0164 & 0.8997 & Not Reject \\
\hline MANU ION does not Granger Cause NBTT $_{\text {ION }}$ & & 2.5395 & 0.1306 & Not Reject \\
\hline MANU $_{\mathrm{ED}}$ does not Granger Cause $\mathrm{NBTT}_{\mathrm{ED}}$ & & 5.2365 & 0.0361 & Reject \\
\hline "MANUWD does not Granger Cause NBTT $_{W D}$ & \multirow{4}{*}{2} & 0.6903 & 0.5189 & Not Reject \\
\hline MANU $_{\text {ING }}$ does not Granger Cause NBTT $_{\text {ING }}$ & & 0.1284 & 0.8806 & Not Reject \\
\hline 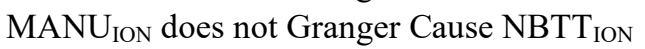 & & 1.9516 & 0.1815 & Not Reject \\
\hline MANU $_{\mathrm{ED}}$ does not Granger Cause $\mathrm{NBTT}_{\mathrm{ED}}$ & & 2.8645 & 0.0932 & Not Reject \\
\hline MANUWD does not Granger Cause NBTT $_{W D}$ & \multirow{4}{*}{3} & 1.1920 & 0.3618 & Not Reject \\
\hline MANU $_{\text {ING }}$ does not Granger Cause NBTT $_{\text {ING }}$ & & 0.1404 & 0.9335 & Not Reject \\
\hline MANU ION $_{\text {does not Granger Cause NBTT }}$ ION & & 1.4110 & 0.2965 & Not Reject \\
\hline MANU $_{\mathrm{ED}}$ does not Granger Cause $\mathrm{NBTT}_{\mathrm{ED}}$ & & 1.7574 & 0.2186 & Not Reject \\
\hline
\end{tabular}

Model results for manufactured goods exported for different economic development status are presented in Table 5 to Table 8. Table 5 demonstrates the impact of changes in MANU ${ }_{\mathrm{WD}}$ to NBTT, $\mathrm{P}_{\mathrm{X}}, \mathrm{P}_{\mathrm{M}}$, and ITT for the world, respectively by Model 1 and Model 2. The dependent variables are positively affected by their oneperiod lagged terms for Model 2, which are consistent to Cashin and Pattillo (2006) for stability. The negative impact of MANUWD to NBTT indicates the deterioration of terms of trade by rapid rising of the proportion of exports of manufactured goods and replacing primary exports as the main driving force for exports, an evidence of confirming the Prebisch-Singer Hypothesis or Theory of Deterioration Terms of Trade (TDTT) during this period. Specifically, a $1 \%$ increase in the proportion of manufactured goods exported for the world (MANU $\mathrm{WD}_{\mathrm{WD}}$ will result $2.72 \%$ decreases in unit value index of exports $\left(\mathrm{P}_{\mathrm{X}}\right)$ and $2.80 \%$ decreases in unit value index of imports $\left(\mathrm{P}_{\mathrm{M}}\right)$, which causes $0.0248 \%$ deterioration in NBTT ${ }_{W D}$. Finally, a $1 \%$ increase in the proportion of 
manufactured goods exported for the world (MANUWD) will result $0.2468 \%$ decreases in ITT, which is mainly a result of increases in volume of goods exported coupled with the negative stimulus of that to NBTT.

Table 5. Model results for manufactured goods exported for the world.

\begin{tabular}{|c|c|c|c|c|c|c|c|c|}
\hline & \multicolumn{4}{|c|}{ Model 1} & \multicolumn{4}{|c|}{ Model 2} \\
\hline & NBTT & $\mathbf{P}_{\mathbf{X}}$ & $\mathbf{P}_{M}$ & ITT & NBTT & $\mathbf{P}_{\mathbf{X}}$ & $\mathbf{P}_{M}$ & ITT \\
\hline $\begin{array}{c}\mathrm{C} \\
\text { (t-statistics) }\end{array}$ & $\begin{array}{l}121.3680 \\
(25.17)^{* *}\end{array}$ & $\begin{array}{l}424.5394 \\
(14.15)^{* *}\end{array}$ & $\begin{array}{l}410.9706 \\
(15.49)^{* *}\end{array}$ & $\begin{array}{c}284.8588 \\
(4.84)^{* * *}\end{array}$ & $\begin{array}{c}11.6819 \\
(1.10)\end{array}$ & $\begin{array}{c}241.4519 \\
(5.06)^{* *}\end{array}$ & $\begin{array}{l}251.5217 \\
(5.53)^{* * *}\end{array}$ & $\begin{array}{c}26.8433 \\
(0.97)\end{array}$ \\
\hline MANU $_{W D}$ & $\begin{array}{c}-33.0750 \\
(-4.71)^{* *}\end{array}$ & $\begin{array}{l}-480.345 \\
(-10.99)^{* *}\end{array}$ & $\begin{array}{l}-459.091 \\
(-11.87)^{* * *}\end{array}$ & $\begin{array}{l}-291.179 \\
(-3.139)^{* *}\end{array}$ & $\begin{array}{c}-2.4777 \\
(0.64)\end{array}$ & $\begin{array}{c}-272.358 \\
(-4.76)^{* *}\end{array}$ & $\begin{array}{c}-280.045 \\
(-5.21)^{* *}\end{array}$ & $\begin{array}{c}-24.6819 \\
(-0.72)\end{array}$ \\
\hline Lagged $_{t-1}$ & & & & & $\begin{array}{l}0.9011 \\
(10.39)^{* *}\end{array}$ & $\begin{array}{l}0.4375 \\
(4.09)^{* * *}\end{array}$ & $\begin{array}{l}0.3918 \\
(3.70)^{* * *}\end{array}$ & $\begin{array}{l}0.9131 \\
(12.28)^{* *}\end{array}$ \\
\hline $\mathrm{R}^{2}$ & 0.5519 & 0.8702 & 0.8868 & 0.3903 & 0.9366 & 0.9317 & 0.9347 & 0.9362 \\
\hline$\overline{\mathrm{R}}^{2}$ & 0.5270 & 0.8630 & 0.8805 & 0.3565 & 0.9287 & 0.9232 & 0.9266 & 0.9282 \\
\hline D-W & 0.2401 & 0.2763 & 0.3156 & 0.1535 & 1.4425 & 1.3306 & 1.3332 & 2.2073 \\
\hline
\end{tabular}

${ }^{*}$ denote significant at $95 \%$ level; ${ }^{* *}$ denote significant at $99 \%$ level

Table 6 demonstrates the impact of changes in MANU ING $_{\text {to NBT, }} \mathrm{P}_{\mathrm{X}}, \mathrm{P}_{\mathrm{M}}$, and ITT for the developing economies by Model 1 and Model 2, respectively. The dependent variables are positively affected by their oneperiod lagged terms for Model 2, which are consistent to Cashin and Pattillo (2006) for stability. The negative impact of MANU $_{\text {ING }}$ to NBTT indicates the deterioration of terms of trade by rapid rising of the proportion of exports of manufactured goods and replacing primary exports as the main driving force for exports, an evidence of confirming the Prebisch-Singer Hypothesis during this period. Specifically, a $1 \%$ increase in the proportion

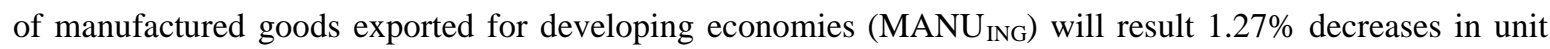
value index of exports $\left(\mathrm{P}_{\mathrm{X}}\right)$ and $1.12 \%$ decreases in unit value index of imports $\left(\mathrm{P}_{\mathrm{M}}\right)$, which causes $0.19 \%$

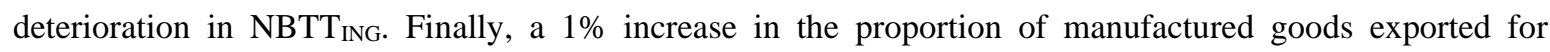
developing economies (MANU $\mathrm{ING}_{\text {) }}$ will result $0.32 \%$ decreases in income terms of trade (ITT).

Table 6. Model results for manufactured goods exported for the developing economies.

\begin{tabular}{|c|c|c|c|c|c|c|c|c|}
\hline & \multicolumn{4}{|c|}{ Model 1} & \multicolumn{4}{|c|}{ Model 2} \\
\hline & NBTT & $\mathbf{P x}_{\mathbf{X}}$ & $\mathbf{P}_{M}$ & ITT & NBTT & $\mathbf{P X}_{\mathbf{X}}$ & $\mathbf{P}_{M}$ & ITT \\
\hline$\underset{\text { (t-statistics) }}{\mathrm{C}}$ & $\begin{array}{c}121.3842 \\
(7.74)^{* *}\end{array}$ & $\begin{array}{c}255.4739 \\
(3.70)^{* *}\end{array}$ & $\begin{array}{c}242.0520 \\
(4.13)^{* *}\end{array}$ & $\begin{array}{c}98.4974 \\
(1.00)\end{array}$ & $\begin{array}{c}26.1501 \\
(2.24)^{*}\end{array}$ & $\begin{array}{c}102.8200 \\
(3.40)^{* *}\end{array}$ & $\begin{array}{c}94.7192 \\
(3.49)^{* *}\end{array}$ & $\begin{array}{c}27.9986 \\
(1.55)\end{array}$ \\
\hline MANU ING $_{\text {ING }}$ & $\begin{array}{c}-33.2272 \\
(-1.59)\end{array}$ & $\begin{array}{c}-249.884 \\
(-2.37)^{* *}\end{array}$ & $\begin{array}{c}-225.073 \\
(-2.51)^{* *}\end{array}$ & $\begin{array}{c}-30.8337 \\
(-0.20)\end{array}$ & $\begin{array}{c}-19.4193 \\
(-1.99)\end{array}$ & $\begin{array}{c}-127.102 \\
(-3.03)^{* *}\end{array}$ & $\begin{array}{c}-112.182 \\
(-3.07)^{* *}\end{array}$ & $\begin{array}{c}-31.7940 \\
(-1.16)\end{array}$ \\
\hline Lagged $_{t-1}$ & & & & & $\begin{array}{l}0.8639 \\
(9.55)^{* *}\end{array}$ & $\begin{array}{l}0.8042 \\
(9.82)^{* *}\end{array}$ & $\begin{array}{l}0.7903 \\
(9.55)^{* * *}\end{array}$ & $\begin{array}{l}0.9533 \\
(21.43)^{* *}\end{array}$ \\
\hline$R^{2}$ & 0.1238 & 0.2371 & 0.2593 & 0.0023 & 0.8677 & 0.8906 & 0.8887 & 0.9663 \\
\hline $\bar{R}^{2}$ & 0.0751 & 0.1947 & 0.2181 & -0.0531 & 0.8512 & 0.8769 & 0.8748 & 0.9621 \\
\hline D-W & 0.1129 & 0.0637 & 0.0678 & 0.0503 & 1.4257 & 1.6856 & 1.6410 & 2.1566 \\
\hline
\end{tabular}

${ }^{*}$ denote significant at $95 \%$ level; ${ }^{* *}$ denote significant at $99 \%$ level

Table 7 demonstrates the impact of changes in MANU $\mathrm{ION}_{\text {to }}$ NBTT, $\mathrm{P}_{\mathrm{X}}, \mathrm{P}_{\mathrm{M}}$, and ITT for transition economies by Model 1 and Model 2, respectively. The dependent variables are all positively affected by their one-period lagged terms for Model 2, which are consistent to Cashin and Pattillo (2006) for stability. The negative impact of MANU ION to NBTT indicates the deterioration of terms of trade by rapid rising of the proportion of exports of manufactured goods and replacing primary exports as the main driving force for exports, an evidence of confirming the Prebisch-Singer Hypothesis during this period. Specifically, a $1 \%$ increase in the proportion of manufactured goods exported for transition economies (MANU ION) will result 7.39\% decreases in unit value index of exports $\left(\mathrm{P}_{\mathrm{X}}\right)$ and $1.75 \%$ decreases in unit value index of imports $\left(\mathrm{P}_{\mathrm{M}}\right)$, which causes $4.84 \%$ deterioration in NBTT. Finally, a $1 \%$ increase in the proportion of manufactured goods exported for transition economies (MANU ${ }_{\text {ION }}$ ) will result $4.29 \%$ decreases in income terms of trade (ITT). 
Table 7. Model results for manufactured goods exported for the transition economies.

\begin{tabular}{|c|c|c|c|c|c|c|c|c|}
\hline & \multicolumn{4}{|c|}{ Model 1} & \multicolumn{4}{|c|}{ Model 2} \\
\hline & NBTT & $\mathbf{P}_{\mathbf{X}}$ & $\mathbf{P}_{M}$ & ITT & NBTT & $\mathbf{P}_{\mathbf{X}}$ & $\mathbf{P}_{\mathbf{M}}$ & ITT \\
\hline$\underset{\text { (t-statistics) }}{\mathrm{C}}$ & $\begin{array}{c}244.2703 \\
(14.34)^{* *}\end{array}$ & $\begin{array}{c}356.2644 \\
(12.89)^{* *}\end{array}$ & $\begin{array}{c}215.7387 \\
(12.91)^{* *}\end{array}$ & $\begin{array}{c}296.4124 \\
(11.00)^{* *}\end{array}$ & $\begin{array}{c}214.9303 \\
(4.42)^{* * *}\end{array}$ & $\begin{array}{c}260.7991 \\
(4.35)^{* *}\end{array}$ & $\begin{array}{c}77.7026 \\
(3.28)^{* *}\end{array}$ & $\begin{array}{c}165.8740 \\
(3.08)^{* *}\end{array}$ \\
\hline MANUION $_{\text {ION }}$ & $\begin{array}{c}-550.804 \\
(-8.17)^{* *}\end{array}$ & $\begin{array}{c}-1,010.6 \\
(-9.24)^{* *}\end{array}$ & $\begin{array}{c}-485.776 \\
(-7.34)^{* *}\end{array}$ & $\begin{array}{c}-749.915 \\
(-7.46)^{* *}\end{array}$ & $\begin{array}{l}-484.079 \\
(-3.89)^{* *}\end{array}$ & $\begin{array}{c}-739.334 \\
(-3.99)^{* *}\end{array}$ & $\begin{array}{c}-174.790 \\
(-2.85)^{*}\end{array}$ & $\begin{array}{c}-429.357 \\
(-2.67)^{*}\end{array}$ \\
\hline Lagged $_{t-1}$ & & & & & $\begin{array}{c}0.1210 \\
(0.63)\end{array}$ & $\begin{array}{c}0.2771 \\
(1.75)\end{array}$ & $\begin{array}{l}0.6556 \\
(6.24)^{* *}\end{array}$ & $\begin{array}{c}0.4238 \\
(2.51)^{*}\end{array}$ \\
\hline $\mathrm{R}^{2}$ & 0.7875 & 0.8258 & 0.7496 & 0.7554 & 0.7733 & 0.8382 & 0.9191 & 0.8065 \\
\hline$\overline{\mathrm{R}}^{2}$ & 0.7757 & 0.8161 & 0.7357 & 0.7418 & 0.7449 & 0.8180 & 0.9090 & 0.7823 \\
\hline D-W & 1.8827 & 1.7390 & 0.6556 & 1.2261 & 1.9572 & 2.1092 & 1.8517 & 1.8755 \\
\hline
\end{tabular}

${ }^{*}$ denote significant at $95 \%$ level; ${ }^{* *}$ denote significant at $99 \%$ level

Table 8 demonstrates the impact of changes in MANU $\mathrm{ED}_{\mathrm{ED}}$ to NBTT, $\mathrm{P}_{\mathrm{X}}, \mathrm{P}_{\mathrm{M}}$, and ITT to developed economies by Model 1 and Model 2, respectively. The dependent variables are all positively affected by their one-period lagged terms for Model 2, which are consistent to Cashin and Pattillo (2006) for stability. The positive impact of MANU $\mathrm{ED}_{\text {to }}$ to $\mathrm{NTT}$ indicates the improvement of terms of trade by rapid rising of the proportion of exports of manufactured goods and replacing primary exports as the main driving force for exports, an evidence of violating the Prebisch-Singer Hypothesis during this period. Specifically, a $1 \%$ increase in the

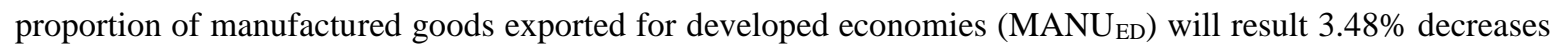
in unit value index of exports $\left(\mathrm{P}_{\mathrm{X}}\right)$ and $4.59 \%$ decreases in unit value index of imports $\left(\mathrm{P}_{\mathrm{M}}\right)$, which causes $0.45 \%$ improvement in NBTT. Finally, a $1 \%$ increase in the proportion of manufactured goods exported for developed

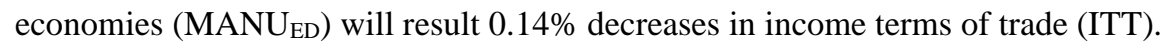

Table 8. Model results for manufactured goods exported for the developed economies.

\begin{tabular}{|c|c|c|c|c|c|c|c|c|}
\hline & \multicolumn{4}{|c|}{ Model 1} & \multicolumn{4}{|c|}{ Model 2} \\
\hline & NBTT & $\mathbf{P}_{\mathbf{X}}$ & $\mathbf{P}_{\mathbf{M}}$ & ITT & NBTT & $\mathbf{P}_{\mathbf{X}}$ & $\mathbf{P}_{\mathbf{M}}$ & ITT \\
\hline$\underset{\text { (t-statistics) }}{\mathrm{C}}$ & $\begin{array}{l}65.3748 \\
(12.11)^{* *}\end{array}$ & $\begin{array}{c}442.1723 \\
(15.23)^{* *}\end{array}$ & $\begin{array}{c}471.5960 \\
(15.94)^{* *}\end{array}$ & $\begin{array}{c}264.4736 \\
(6.86)^{* *}\end{array}$ & $\begin{array}{c}54.7111 \\
(3.71)^{* *}\end{array}$ & $\begin{array}{c}333.6765 \\
(2.84)^{*}\end{array}$ & $\begin{array}{c}428.2463 \\
(3.59)^{* *}\end{array}$ & $\begin{array}{c}20.6520 \\
(0.52)\end{array}$ \\
\hline MANUED & $\begin{array}{c}48.6014 \\
(6.60)^{* *}\end{array}$ & $\begin{array}{c}-469.684 \\
(-11.86)^{* *}\end{array}$ & $\begin{array}{c}-510.751 \\
(-1.65)^{* *}\end{array}$ & $\begin{array}{c}-237.840 \\
(-4.52)^{* *}\end{array}$ & $\begin{array}{c}45.2523 \\
(3.63)^{* *}\end{array}$ & $\begin{array}{c}-347.967 \\
(-2.70)^{*}\end{array}$ & $\begin{array}{c}-459.386 \\
(-3.45)^{* *}\end{array}$ & $\begin{array}{c}-13.9902 \\
(-0.34)\end{array}$ \\
\hline Laggedt-1 & & & & & $\begin{array}{c}0.1305 \\
(0.64)\end{array}$ & $\begin{array}{c}0.2056 \\
(0.83)\end{array}$ & $\begin{array}{c}0.0642 \\
(0.27)\end{array}$ & $\begin{array}{l}0.9035 \\
(6.99)^{* *}\end{array}$ \\
\hline $\mathrm{R}^{2}$ & 0.7073 & 0.8865 & 0.8989 & 0.5317 & 0.7308 & 0.8852 & 0.8916 & 0.8724 \\
\hline$\overline{\mathrm{R}}^{2}$ & 0.6911 & 0.8802 & 0.8932 & 0.5057 & 0.6972 & 0.8709 & 0.8781 & 0.8564 \\
\hline D-W & 1.4257 & 0.6966 & 0.8564 & 0.3790 & 1.7275 & 1.0508 & 1.0218 & 2.1791 \\
\hline
\end{tabular}

${ }^{*}$ denote significant at $95 \%$ level; ${ }^{* *}$ denote significant at $99 \%$ level

\section{Conclusions and Discussion}

The structure of export commodities has changed dramatically for economies in different development status and it deserves to examine the existence of the Prebisch-Singer Hypothesis on the deterioration of terms of trade. Using data of manufactured goods from UNCTAD, the proportion of exports of manufactured goods for different development status is used to investigate the relative impacts to alternative expressions of terms of trade. The results show that the Prebisch-Singer Hypothesis holds for most economies except the developed economies only. In the long term, for every $1 \%$ increase in exports of manufactured goods, the terms of trade of exports for the world, developing economies, and transition economies deteriorated by $0.025 \%, 0.19 \%$ and $4.84 \%$ respectively, while the terms of trade of exports for developed economies improved by $0.45 \%$.

The theory of Deterioration Terms of Trade holds in this study for most of the economies except the developed ones that the NBTT deteriorates as the proportion of exports of manufactured goods. There is a longterm and stable relationship between terms of trade and the proportion of manufactured goods exported. Regarding the manufactured goods exported for developing economies continuously increasing from 2000 to 
2019 , the results are persuasible to the literature. The increases in the proportion of exports of manufactured goods for developing economies are the main cause of the change in the terms of trade, which can also have a derivative effect on the income terms of trade, which in turn affects national income. In the long run, the enduring and worsening trend is a related phenomenon of commodity trade since a large part of commodity trade between developing and developed economies is the vertical exchange of commodities from developing economies in exchange for manufactured goods from developed economies. In recent years, the expansion of exports of manufactures goods from developing economies is no longer confined to a relatively small number of economies. The main exchange between developing and developed economies has gradually become a horizontal exchange between other manufactured goods. This change in the structure of trade has led to the expansion of the terms of trade for manufactured-to-manufactured goods, making the hypothesis of deterioration of terms of trade between economies in different developing countries worth further exploration.

\section{References}

1. Ardeni, P. G., \& Wright, B. D. (1992). The Prebisch-Singer Hypothesis: A Reappraisal Independent of Stationarity Hypotheses. Economic Journal, 102(413): 803-812.

2. Cashin, P., \& Pattillo, C. (2006). African Terms of Trade and the Commodity Terms of Trade: Close Cousins or Distant Relatives? Applied Economics, 38(8): 845-859.

3. Emmanuel, A. (1969). Unequal Exchange: A Study in the Imperialism of Trade. New York and London: Monthly Review Press.

4. Funke, M., \& Ruhwedel, R. (2005). Export Variety and Economic Growth in East European Transition Economies. Economics of Transition, 13(1): 25-50.

5. Geronimi, V., \& Taranco, A. (2018). Revisiting the Prebisch-Singer Hypothesis of a Secular Decline in the Terms of Trade of Primary Commodities (1900-2016)-A Dynamic Regime Approach. Resources Policy, 59: 329-339.

6. Li, G. J., \& Cao, Y. Q. (2005). An Empirical Analysis of the Similarity Theory of Demand Preferences in China's Trade. Journal of Yunnan University of Finance and Trade, 3: 27-32.

7. Lutz, M. G. (1999). A General Test of the Prebisch-Singer Hypothesis. Review of Development Economics, 3: 44-57.

8. Sapsford, D., \& Chen, J. R. (1998). The Prebisch-Singer Terms of Trade Hypothesis: Some (Very) New Evidence. Palgrave Macmillan, UK.

9. Sarkar, P. (1986). The Singer-Prebisch Hypothesis: A Statistical Evaluation. Cambridge Journal of Economics, 10(4): 355-371.

10. Sarkar, P., \& Singer, H. W. (1991). Manufactured Exports of Developing Economies and Their Terms of Trade since 1965. World Development, 19(4): 333-340.

11. Wacker, K. M., Grosskurth, P., \& Lakemann, T. (2016). Foreign Direct Investment, Terms of Trade, and Quality Upgrading: What Is so Special about South Asia? Asian Development Review, 33(1): 28-55.

12. Witkowska, E. A. (2016). Reconsideration of the Prebisch-Singer Hypothesis. Real-world Economics Review, 76: 95 108.

13. Zeng, Z., \& Hu, X. H. (2005). Clarification on the Actuality Upgrading Exporting Commodity Structure and Deterioration of Trade Terms Coexist in China. Finance \& Economics, 4: 162-168. 